\title{
A Lytic Lesion on the Head of the Fifth Metatarsal Bone Mimicking Rheumatoid Arthritis in a Geriatric Patient
}

\author{
Geriatrik Bir Olguda Beşinci Metatars Başında Romatoid Artriti Taklit Eden Litik Lezyon
}

\author{
Metin IŞIK \\ Department of Internal Medicine, Medical Faculty of Hacettepe University, Division of Rheumatology, Ankara, Turkey
}

Here we present a 75-year-old female patient who presented to our outpatient clinic with arthralgia localized to the metatarsophalangeal (MTP) joints which had lasted for 12 months. On her physical examination, the fifth metatarsophalageal joint was tender and swollen, but there were no signs of any redness or increased warmth. The sedimentation rate (sed rate) was $25 \mathrm{~mm} /$ hour, and the level of C-reactive protein (CRP) was $1.4 \mathrm{mg} / \mathrm{dL}$ (range $0-0.8$ ). The rheumatoid factor (RF) was $45 \mathrm{IU} / \mathrm{ml}$ (range 0-20), and the anti-cyclic citruline peptide (anti-CCP) was $39 \mathrm{U} / \mathrm{ml}$ (range 0-25). On the radiological evaluation, an X-ray revealed a lytic lesion on the head of the fifth metatarsal bone. The patient had no inflammatory arthritis; therefore, she was treated as though she had osteoarthritis. After taking paracetamol (4x500 mg/day), she improved. After a more thorough medical inquiry, it was learned that a traumatic fracture of the fifth MTP joint had occurred 13 years previously and that the radiological findings had been accepted as post-traumatic changes. It was now concluded that she had rheumatoid arthritis (RA).

Rheumatoid arthritis is an autoimmune, chronic, inflammatory disease of the joints and may lead to MTP joint erosions, periarticular osteopenia, and soft tissue swelling. These erosions first occur and are most frequent at the fifth MTP joint. ${ }^{[1]}$

A history of previous trauma may present confusion in the diagnosis of RA, and it may be difficult to diagnose a geriatric patient with RA since the clinical findings may be insignificant. In addition, nearly $25 \%$ of geriatric patients have increased RF and sometimes have slightly increased anti-CCP levels. ${ }^{[2]}$ For these patients, significantly elevated levels of the sed rate, CRP, and, especially, anti-CCP may be very helpful. ${ }^{[3]}$

In conclusion, diagnosis of RA in geriatrics may be prove to be difficult due to RF positivity and insignificant clinical presentation. On the other hand, a radiological exam may also yield confusing and unclear results.

\section{Declaration of conflicting interests}

The authors declared no conflicts of interest with respect to the authorship and/or publication of this article.

\section{Funding}

The authors received no financial support for the research and/or authorship of this article.

\section{REFERENCES}

1. Attar SM, Al-Ghamdi A. Radiological changes in rheumatoid arthritis patients at a teaching hospital in Saudi Arabia. East Mediterr Health J 2010;16:953-7.

2. Birch JT Jr, Bhattacharya S. Emerging trends in diagnosis and treatment of rheumatoid arthritis. Prim Care 2010;37:779-92.

3. Schoels M, Bombardier C, Aletaha D. Diagnostic and prognostic value of antibodies and soluble biomarkers in undifferentiated peripheral inflammatory arthritis: a systematic review. J Rheumatol Suppl 2011;87:20-5.

\footnotetext{
Received: November 9, 2011 Accepted: March 10, 2012

Correspondence: Metin Işık, M.D. Hacettepe Üniversitesi Tıp Fakültesi İç Hastalıkları Anabilim Dalı, Romatoloji Bilim Dalı, 06100 Sıhhiye, Ankara, Turkey. Tel: +90 312 - 5084603 e-mail: metin1721978@yahoo.com

(92012 Turkish League Against Rheumatism. All rights reserved.
} 